\title{
Matkailun taloudelliset vaikutukset: tutkimusmenetelmän pohdintaa ja tuloksia Tunturi-Lapista
}

Pasi Satokangas, Lapin ammattikorkeakoulu, Matkailualan tutkimus- ja koulutusinstituutti (MTI)

\section{Pohjois-Suomessa useita talousvaikutusselvityksiä viime vuosina}

Matkailusta on puhuttu pitkään kasvavana elinkeinona, eikä vähiten viime vuosina. Erityisen merkittävää matkailu on niille reuna-alueiden kunnille, joissa sijaitsee suosittuja matkailukohteita, kuten hiihtokeskuksia. Luoteis-Lapissa sijaitsevaan Tunturi-Lapin seutukuntaan kuuluvat Enontekiön, Kittilän, Kolarin ja Muonion kunnat, ja alueella on yhteensä 14421 asukasta (Tilastokeskus, 2019a). Enontekiön helmiä on Kilpisjärven tunturialue. Kunnassa on myös vilkasta joulumatkailua. Kittilä tunnetaan Levin hiihtokeskuksesta, Kolari Ylläksestä ja Muonio Oloksesta sekä Pallaksesta. Muonioon sijoittuu myös Jerisjärvi hiihtolatuineen ja -reitteineen. Syrjäinen mutta luonnonkaunis sijainti tuo Tunturi-Lappiin omat haasteensa ja mahdollisuutensa. Seudulla onkin pitkään kehitetty matkailua elinkeinona, joka tuo toimeentuloa perinteisempien töiden rinnalla.

Matkailualan tutkimus- ja koulutusinstituutti (MTI) selvitti Tunturi-Lapin Leader ry:n toimeksiannosta matkailun välittömät talousvaikutukset Tunturi-Lapin kunnissa vuonna 2017 (Satokangas, 2019a). Välittömät vaikutukset muodostuvat matkailijoita palvelevissa yrityksissä. Selvityksen kohdetoimialoja olivat vähittäiskauppa, majoitus- ja ravitsemistoiminta, huvi- ja virkistystoiminta sekä liikenne. Tässä puheenvuorossa esitellään selvityksen päätulokset ja pohditaan käytettyä menetelmää sekä sen kehittämistarpeita.

Matkailun talousvaikutuksia Tunturi-Lapin kunnissa on selvitetty aiemminkin esimerkiksi MTI:n toimesta; tuolloin tarkasteluvuosi oli 2011. (Satokangas, 2013). MTI:ssa on viime vuosina selvitetty matkailun talousvaikutuksia myös useissa muissa Lapin kunnissa. Kemi-Tornion seutukuntaa eli Kemin, Keminmaan, Simon, Tervolan ja Tornion kuntien muodostamaa aluetta markkinoidaan matkailijoille Meri-Lapin nimellä. Meri-Lapissa on selvitetty matkailun talousvaikutuksia vuosina 2016 ja 2018 (Satokangas, 2016, 2018). Lisäksi Kemissä selvittiin matkailun talousvaikutuksia vuonna 2014 (Satokangas, 2014). Vuoden 2019 aikana selvitettiin Tunturi-La- 
pin lisäksi matkailun talousvaikutuksia Pyhä-Luostolla (Satokangas, 2019b), Ranualla (Satokangas, 2019c) ja Sodankylässä (Satokangas, 2019d).

Talousvaikutuksia on selvitetty myös muualla Pohjois-Suomessa. Lukuisia selvityksiä on viime vuosina toteutettu etenkin Pohjois-Pohjanmaan kunnissa ja matkailukohteissa. Näistä uusimmissa kohteina ovat olleet Kalajoki, Kuusamo, Oulu, Pudasjärvi ja Vaala (Kauppila, 2019a) sekä Sotkamo (Kauppila, 2019b).

\section{Tulomenetelmäselvitys matkailun talousvaikutuksista Tunturi-Lapissa}

Suomalaisissa matkailun talousvaikutusten selvityksissä on usein käytetty niin sanottua tulomenetelmää, joka viittaa yritysten saamiin matkailutuloihin. Sen perustana on yleensä tilastoaineisto, joka kuvaa toimialojen kokonaisliikevaihtoa ja -työllisyyttä tutkittavalla alueella. Tilastoaineistoa täydennetään yrityskyselyllä, jolloin saadaan selville matkailun osuus liikevaihdosta ja työllisyydestä. Tutkimusmenetelmiä on mahdollista soveltaa eri tavoin, eikä tulomenetelmä tee tässä poikkeusta. Menetelmä pohjautuu 1970-luvulla kehitettyyn Pohjoismaiseen malliin, jossa määritettiin keskeiset periaatteet matkailun vaikutusten selvittämiseen. Pohjoismaista mallia voidaan kuitenkin pitää enemmän työkalupakkina kuin täsmällisenä metodina. Sittemmin Pohjoismaista mallia on kehitetty edelleen tietojen vertailukelpoisuuden parantamiseksi. Tämä tapahtuu lähinnä vakioimalla menetelmää ja sen soveltamista. Yksi tärkeimmistä keinoista vertailukelpoisuuden parantamisessa on yhdenmukaisen toimialaluokituksen käyttäminen. Muun muassa Koillismaan malli on kehitetty Pohjoismaisen mallin pohjalta. (Satokangas, 2017, s. 112.)

Tunturi-Lapin vuotta 2017 koskevan yrityskyselyn vastausjakauma toimialoittain ja kunnittain on esitetty taulukossa 1 . Kysely kohdistettiin etenkin toimialojen suurimpiin edustajiin tutkittavissa kunnissa, jotta matkailuosuusprosenttien laskenta perustuu mahdollisimman kattavaan otokseen suhteessa toimialojen kokonaisliikevaihtoihin. Kyselyn kohteena olivat myös useat pienet toimipaikat, mutta suurempien toimijoiden osallistuminen pyrittiin varmistamaan ottamalla niihin aktiivisesti yhteyttä. Vastauksia kerättiin sähköpostikyselyllä, jota täydennettiin pyytämällä vastauksia puhelimitse. Kyselyn toteutuksessa oli mukana Lapin ammattikorkeakoulun tradenomiopiskelijoita.

Taulukko 1. Tunturi-Lapin yrityskyselyn vastausmäärät kunnittain ja toimialoittain.

\begin{tabular}{lccccc} 
& ENONEKIÖ & KITTILÄ & KOLARI & MUONIO & YHTEENSÄ \\
Vähittäiskauppa & 7 & 16 & 11 & 8 & 42 \\
\hline $\begin{array}{l}\text { Majoitus- ja } \\
\text { ravitsemistoiminta }\end{array}$ & 11 & 17 & 17 & 16 & 61 \\
\hline Huvi- ja virkistystoiminta & 11 & 15 & 15 & 13 & 54 \\
\hline Liikenne & 10 & 9 & 10 & 8 & 37 \\
\hline Yhteensä & 39 & 57 & 53 & 45 & 194 \\
\hline
\end{tabular}


Määrällisiä tuloksia arvioitaessa herää kysymys, ovatko matkailun vaikutuksia kuvaavat luvut suuria vai pieniä. Tätä voidaan arvioida esimerkiksi vertaamalla lukuja aikaisempaan tilanteeseen, jos varhaisempia tietoja on käytettävissä. Tunturi-Lapissa suuntaa antava vertailu on mahdollista.

Aiempi, vuotta 2011 koskeva selvitys matkailun tulo- ja työllisyysvaikutuksista TunturiLapissa oli osa laajempaa 12 lappilaisen kunnan selvitystä. Tuolloin vastauksia jouduttiin vastauskadon vuoksi yhdistelemään laskettaessa matkailun osuutta yritysten liikevaihdosta, ja kohdekunnista muodostettiin kaksi ryhmää. Matkailuosuusprosentit eivät siis olleet kuntakohtaisia vaan edustivat kuntaryhmään kuuluvien kuntien keskiarvoa. Toimialojen kokonaisliikevaihtoa kuvaava tieto oli sitä vastoin aiemmassakin tutkimuksessa kuntakohtainen.

Selvitysten menetelmissä oli muitakin eroja. Matkailutyöllisyys laskettiin vuotta 2011 koskevassa selvityksessä henkilöstö/liikevaihtosuhteiden avulla matkailutulon pohjalta. Laskentatapa kattaa käytännössä myös vuokratyöllisyyden, koska laskennan pohjana oleva matkailutulo on muodostunut paitsi yritysten itse palkkaamien myös vuokratyösuhteessa olevien työntekijöiden panoksen johdosta. Vuotta 2017 koskevassa selvityksessä matkailutyöllisyys laskettiin Tilastokeskuksen yritysrekisterin toimialojen kokonaistyöllisyyttä kuvaavista tiedoista toimialojen matkailuosuusprosenttien avulla. Tämä laskentatapa on nopeasti sovellettava, mutta vuokratyövoiman luokka ei ole mukana käytetyissä aineistoissa eli mahdollinen vuokratyövoima jää laskelmien ulkopuolelle. Vuokratyövoimaa käytetään monilla eri aloilla, joten mikäli vuokratyövoimaa tarjoavien yritysten tilastoluokka haluttaisiin sisällyttää aineistoon, matkailun osuus tulisi erottaa vuokratyövoiman kokonaistyöllisyydestä. Mainituista eroista johtuen työllisyyslaskelmat eivät ole vertailukelpoisia aiemman tutkimuksen kanssa.

Tilastokeskuksen yritysrekisteri uudisti tilastointitapoja vuonna 2013. Tuolloin tilastointiin otettiin mukaan uutena ryhmänä 170000 euron taserajan ylittävät yritykset. Aiemmin mukana olivat vain ne yritykset, jotka ylittivät vuosittain määritellyn liikevaihdon kynnyksen (10 846 euroa vuonna 2013) tai joiden työllistävyys oli vähintään puoli henkilötyövuotta. Lisäksi tietojen keräämisen tavoissa tapahtui muutoksia. Uudistusten johdosta yritysten lukumäärä vuositilastossa on kasvanut; suurin lisäys on tapahtunut alkutuotannon alalla. (Tilastokeskus, 2018.) Tilastointikäytäntöjen muutoksen tarkkaa vaikutusta on vaikea arvioida, mutta Tilastokeskuksen ilmoittamat tiedot uudistuksesta ja eri vuosien selvitystuloksia koskevat havainnot viittaavat siihen, että matkailun toimialoilla vaikutus ei ole ollut ainakaan huomattava.

Edellä mainituista syistä myöhemmin esitettävä vuosien 2011 ja 2017 matkailutuloa koskeva vertailu on siis suuntaa antava.

\section{Matkailun tuottamat tulot ja työpaikat Tunturi-Lapissa}

Taulukossa 2 on esitetty matkailun välittömät vaikutukset Tunturi-Lapissa vuonna 2017. Välitön matkailutulo oli yhteensä noin 290 miljoonaa euroa. Luvut eivät sisällä arvonlisäveroa. Välitön matkailutyöllisyys oli puolestaan noin 1500 henkilötyövuotta. Henkilötyövuosi tarkoittaa yhden henkilön vuoden aikana tekemää täysiaikaista työpanosta. Mikäli yrityksessä työskentelee 
esimerkiksi säännöllisesti yksi täysiaikainen ja yksi puoliaikainen henkilö, muodostuu vuoden aikana yhteensä 1,5 henkilötyövuotta. Alueen koko matkailutulosta noin puolet (52 \%) ja työllisyydestä vielä hieman suurempi osuus (56 \%) muodostui Kittilässä.

Taulukko 2. Matkailun välittömät tulo- ja työllisyysvaikutukset Tunturi-Lapissa vuonna 2017.

\begin{tabular}{lrr} 
& \multicolumn{1}{c}{$\begin{array}{r}\text { MATKAILUTULO } \\
\text { Enontekiö }\end{array}$} & MATKAILUTYÖLLISYYS \\
Kittilä & 26701840 & 121 \\
\hline Kolari & 149859430 & 866 \\
\hline Muonio & 71907570 & 366 \\
\hline Yhteensä & 42027340 & 194 \\
\hline
\end{tabular}

Kuntien välillä oli eroja siinä, missä suhteessa matkailun eri toimialat tuottivat yrityksille tuloja. Tämä kuvastaa Tunturi-Lapin kuntien erilaisia matkailullisia profiileja. Kittilässä, Kolarissa ja Muoniossa majoitus- ja ravitsemistoimialan matkailutulo oli merkittävin. Kaikkein eniten majoitus- ja ravitsemistoimiala painottui Muoniossa. Kolarissa vähittäiskauppa toi matkailutuloa lähes yhtä paljon kuin majoitus- ja ravitsemistoiminta. Enontekiöllä matkailutuloa muodostui vähittäiskaupan alalla hieman enemmän kuin majoitus- ja ravitsemisalalla. Kittilässä huvi- ja virkistystoimiala oli poikkeuksellisen merkittävä matkailutulon tuoja.

Kuten edellä todettiin, matkailutuloa koskevia tuloksia voidaan suuntaa antavasti verrata aiempaan, vuotta 2011 koskevaan selvitykseen (Satokangas, 2013). Vertailussa kunkin kunnan vuotta 2011 koskeva matkailutulo on deflatoitu Tilastokeskuksen elinkustannusindeksillä vuoden 2017 arvoon, jolloin vertailusta on suodatettu pois rahanarvon muutos (Tilastokeskus, 2019b). Deflatoinnin jälkeen matkailutulon kasvu välillä 2011-2017 oli Enontekiöllä 3,7 miljoonaa euroa (13,9 \%), Kittilässä 26,5 miljoonaa euroa (18 \%), Kolarissa 15,8 miljoonaa euroa (22 \%) ja Muoniossa 13,1 miljoonaa euroa (44\%).

\section{Pohdinta}

Matkailun talousvaikutusten selvittämisessä käytettävä tulomenetelmä perustuu yleensä kahteen perusaineistoon. Tilastokeskukselta hankitaan selvityksen pohjaksi toimialojen kokonaisliikevaihtoja ja -työllisyyttä kohdealueella koskevat tiedot. Matkailun osuus näiden toimialojen tulo- ja työllisyysvaikutusten muodostumisessa selvitetään useimmiten yrityskyselyllä. Kyselyt on helppo lähettää vastaanottajille sähköpostitse, mutta erilaisten kyselyjen ja muun sähköpostiviestinnän lisääntyminen aiheuttaa huomattavaa vastauskatoa.

Mitä enemmän kyselyssä on kysymyksiä, sitä haluttomampia yrittäjät ovat todennäköisesti vastaamaan. Edellä esitellyssä Tunturi-Lapin selvityksessä vastausten saaminen pyrittiin tur- 
vaamaan kysymällä vain matkailun osuutta kokonaisliikevaihdosta. Tämä onnistuikin hyvin mutta edellytti lukuisia puhelinsoittoja yrityksiin. Vastaavanlaisia pelkistettyjä kyselyjä käytetään nykyään yhä yleisemmin pitkien kyselyjen sijaan. Kysymällä useampia kysymyksiä saataisiin toisaalta tarkempaa tietoa juuri kyseisen kohdealueen matkailun taloudellisista piirteistä. Jos esimerkiksi kysytään vastaajan edustaman toimipaikan liikevaihtoa, vastaajien ilmoittamia matkailuosuusprosentteja voidaan painottaa kyseisellä tiedolla. Painotettu laskenta kuvaa painottamatonta keskiarvoa tarkemmin matkailun merkitystä kohdetoimialoilla.

Kyselyjen lisäksi tietoa yritysten toiminnan kokoluokasta on mahdollista saada erilaisista yrityshakemistoista ja tilastoista. Nämä tiedot eivät tosin aina ole riittävän tarkkoja, jotta ne täyttäisivät tutkijan tarkoitusperät - esimerkiksi ketjuyrityksistä ei ole saatavilla toimipaikkakohtaisia tietoja liikevaihdosta. Tällöinkin painottamista voidaan tehdä soveltamalla käytettävissä olevia tietoja tutkijan harkinnan mukaan. Tunturi-Lapin selvityksessä käytettiin joissakin tapauksissa laskentamenetelmää, joka perustui Tilastokeskuksen antamiin tietoihin yrityksen henkilömäärästä kunnassa. Henkilömäärätiedon sekä kohdekuntaa ja kyseistä toimialaa koskevan henkilöstö/liikevaihtosuhteen avulla on mahdollista laskea arvio toimipaikkakohtaisesta liikevaihdosta. Matkailuosuusprosentin muodostaminen tulomenetelmäselvityksissä tapahtuu tietyin perusperiaattein, joita voidaan kuitenkin soveltaa hieman eri tavoin. Esimerkiksi vastausten painottamisen mahdollisuuksia ja vaikutuksia olisi hyvä tutkia jatkossa lisää.

Tulomenetelmällä saatavan tiedon ajantasaisuus herättää kysymyksiä. Esimerkiksi edellä esitellyt tulokset koskevat vuotta 2017. Tämä voi antaa lukijalle vaikutelman, että kyseessä ovat jo vanhat tiedot. Tilastomaailmassa tieto on kuitenkin vasta noin vuoden vanha, koska vuotta 2017 kuvaavat tilastotiedot julkaistiin tammikuussa 2019. Tilastoviive on siis melko pitkä. Tunturi-Lappia koskeva selvitys käynnistettiin heti vuoden 2019 alkupuolella, ja alustavat tulokset valmistuivat kevään 2019 aikana. Sidosryhmien edustajat kommentoivat selvitystä kesällä ja syksyllä, ja kommenttien perusteella kyselyä täydennettiin keräämällä lisää vastauksia. Lopulliset tulokset julkaistiin loppusyksyllä 2019.

Tilastoviiveeseen ei ole mahdollista vaikuttaa, mutta muulla tavoin prosessia voi nopeuttaa. Yrityskysely ei ole riippuvainen vuositilastosta, joten kyselyn toteutus kannattaa aloittaa pian sen jälkeen, kun päätös selvityksen tekemisestä - käytännössä rahoituksesta - on tehty. Tosin juuri päätöksenteko on monesti ensimmäinen viiveen aiheuttaja, koska asiaa käsitellään esimerkiksi kunnallisissa luottamuselimissä, joilla on omat aikataulunsa. Varsinaisen selvitystyön eteneminen riippuu vuositilaston valmistumisen ohella muun muassa yrityskyselyn sujuvuudesta. Tähän taas vaikuttaa kohdealueen laajuus ja käytettävissä olevat henkilöresurssit. Yleensä kysely ei kuitenkaan ole merkittävä viiveen aiheuttaja. Riittävän tiivis yhteistyö sidosryhmien, kuten selvityksen tilaajan, kanssa sekä suunnittelu- että kommentointivaiheessa nopeuttaa osaltaan tulosten valmistumista.

Vuonna 2019 toteutetussa selvityksessä kerättiin huomattava empiirinen aineisto, joka kuvaa matkailun merkitystä Tunturi-Lapissa eri toimialoilla. Kerättyä tietoa voidaan soveltaa matkailun vaikutusten seurannassa myös tulevaisuudessa. Uudet selvitykset on mahdollista toteuttaa useiden vuosien ajan päivittämällä tilastotiedot. Nyt tehty työ rakensi näin pohjaa tulevalle matkailun vaikutusten seurannalle. 


\section{Lähteet}

Kauppila, P. (2019a). Matkailun aluetaloudellisten vaikutusten seurantamalli: Kalajoki, Kuusamo, Oulu, Pudasjärvi ja Vaala. (Kajaanin ammattikorkeakoulun julkaisusarja B. Raportteja ja selvityksiä 90.) Haettu osoitteesta https://www.theseus.fi/bitstream/handle/10024/167987/Kalajoki_Kuusamo_Oulu_Pudasjarvi_Vaala_seurantamalli\%202019_valmis.pde?sequence $=5$ \&isAllowed=y

Kauppila, P. (2019b). Matkailun aluetaloudellisten vaikutusten seurantamalli: Sotkamo. (Kajaanin ammattikorkeakoulun julkaisusarja B. Raportteja ja selvityksiä 89.) Haettu osoitteesta https:// www.theseus.fi/bitstream/handle/10024/168010/Sotkamo_seurantamalli\%202019_valmis. pdf? sequence $=5$ \&isAllowed $=y$

Satokangas, P. (2013). Matkailulla maakunta menestyy, matkailun tulo- ja työllisyysvaikutukset 12 lappilaisessa kunnassa vuonna 2011. Julkaisematon selvitysraportti.

Satokangas, P. (2014). Matkailun tulo- ja työllisyysvaikutukset Kemissä vuonna 2012. Lapin yliopisto. Julkaisematon selvitysraportti.

Satokangas, P. (2016). Matkailun välittömät tulo- ja työllisyysvaikutukset Meri-Lapissa vuonna 2014. Lapin ammattikorkeakoulu. Julkaisematon selvitysraportti.

Satokangas, P. (2017). Matkailun aluetalousvaikutukset. Teoksessa J. Edelheim \& H. Ilola (toim.), Matkailututkimuksen avainkäsitteet (s. 109-114). Rovaniemi: Lapland University Press.

Satokangas, P. (2018). Matkailun välittömät tulo- ja työllisyysvaikutukset Meri-Lapissa vuonna 2016. Lapin ammattikorkeakoulu. Julkaisematon selvitysraportti.

Satokangas, P. (2019a). Matkailun välittömät tulo- ja työllisyysvaikutukset Tunturi-Lapissa. Lapin ammattikorkeakoulu. Julkaisematon selvitysraportti.

Satokangas, P. (2019b). Matkailun tulo- ja työllisyysvaikutukset Pyhä-Luostolla vuonna 2017. Lapin ammattikorkeakoulu. Julkaisematon selvitysraportti.

Satokangas, P. (2019c). Matkailun välittömät tulo- ja työllisyysvaikutukset Ranualla vuonna 2017. Lapin ammattikorkeakoulu. Julkaisematon selvitysraportti.

Satokangas, P. (2019d). Matkailun välittömät tulo- ja työllisyysvaikutukset Sodankylässä vuonna 2017. Lapin ammattikorkeakoulu. Julkaisematon selvitysraportti.

Tilastokeskus (2018). Yritysrekisterin vuositilaston muutokset yritystilastouudistuksessa. Sähköposti 3.9.2019, Kokkonen Virve - Satokangas Pasi.

Tilastokeskus (2019a). Tunturi-Lapin seutukunta, Väestö 31.12. Haettu osoitteesta http://pxnet2. stat.fi/PXWeb/pxweb/fi/StatFin/StatFin_vrm_vaerak/statfin_vaerak_pxt_11ra.px/table/tableViewLayout1/

Tilastokeskus (2019b). Elinkustannusindeksi 1951:10=100 muuttujina Kuukausi, Vuosi ja Tiedot. Haettu osoitteesta http://pxnet2.stat.fi/PXWeb/pxweb/fi/StatFin/StatFin_hin_khi_vv/ statfin_khi_pxt_11xm.px/table/tableViewLayoutı/ 